\title{
Research on the Assessment System Construction of EAP Writing Skill from an Eco-linguistic Perspective
}

\author{
Jinzhu Zhang \\ School of Humanities, Tianjin Polytechnic University, Tianjin, China
}

\begin{abstract}
This paper comes up with an assessment system of EAP writing development from an Eco-linguistic perspective based on a literature review of English writing construction and assessment of writing skills development under an ecological dynamic model. The paper clarifies that the writing construction in academic contexts consists of genre and rhetorical knowledge, process, strategy knowledge, and academic discourse community knowledge. The paper elucidates that the ecological dynamic assessment of EAP writing skills, as just being conducted at Tianjin Polytechnic University, has been proved to be workable in establishing bio-ecological links between the classroom learning contexts and the broader educational contexts at university. In the research, the individualized and comprehensive employment of assessment tools such as textual analysis, one-on-one interviews, case study and writing portfolios helps achieve dynamic assessment and facilitate ecological transfer of EAP writing competence.
\end{abstract}

Index Terms-EAP, writing skill, Eco-linguistics, ecological dynamic assessment

\section{INTRODUCTION}

Eco-linguistics, which combines ecology and linguistics, is a branch of linguistics that has developed quickly internationally in recent decades. It is different from traditional linguistics in which language systems are regarded as self-contained structural systems. Eco-linguistics holds that language systems are open ecosystems, That is, the two main research paths in the field of Eco-linguistics are Halliday's Environmental Linguistic Model and Haugen's Model of Language Ecology. As for the two research paths mentioned above, the former focuses on the influence and function of language on the ecological environment. The latter studies the factors affecting language function (Fill \& Mühlhusler, 2001; Fan, 2005; Wang, 2007; Huang, 2016).

In this paper, an assessment system for the development of EAP writing ability is constructed by integrating individual language learners with group language teachers (both in and outside the classroom) and cultural environment. The purpose of this study is to promote the teaching and assessment of EAP writing and to improve students' EAP writing ability.

\section{LITERATURE REVIEW}

Eco-writing and the trend of ecological dynamic assessment of English writing

\section{A. Constructs of Eco-writing}

Eco-linguistics is an emerging branch of linguistics which mainly studies the interaction between language and environment (natural and social environment). The fields of Eco-linguistics involve research from the psychological level (bilingual or multilingual people of different language interaction in the brain) as well as social level (interactive language users and Society) (Haugen, 2001). Ecological writing constructs describe writing ability from the dynamic perspective of linguistic ecology. Research on Eco-writing from different contexts has been carried out in recent years. Smit (2004) defined writing in social contexts as a series of knowledge system, which includes content knowledge, general knowledge, form knowledge, condition or program knowledge, specific task knowledge and discourse community knowledge. And he points out that different types of writing tasks requires different social context knowledge and ability. Meanwhile, he asserts that the judgement only based on writing text syntax and rhetoric may conceal the true nature of writing.

Based on the conception of Smit (2004), Beaufort (2007) further clarifies that the writing ability includes five knowledge contents, such as the discourse community knowledge, rhetoric knowledge, genre knowledge and subject knowledge, among which, particular emphasis is given to the discourse community knowledge. It is believed that a good writer can analyze and respond to the assessment and expectation of a particular audience and the knowledge of discourse community in writing determines the choice of genre rhetoric themes and the writing process (Beaufort, 2007). 
Slomp (2012) argues that meta-cognitive knowledge is the basis for the application of all kinds of knowledge: Meta-cognitive knowledge analysis, that is, the motivation of students to conceive and write, can more comprehensively describe the development of their writing ability. Introspection Diaries in the assessment Model of portfolio is an effective way for students to demonstrate their Developments in Meta-cognitive knowledge.

Llosa et al. (2011) also put forward the idea of ecological writing in the process of developing the assessment of writing ability. It combines systemic-functional focus (focus on genre and purpose), cognitive focus (focus on process and strategy) and social perspective (focus on the choice made by the author according to the specific purpose of writing in a specific social context).

Studies outside China have been advocating the idea that English writing ability should be illustrated from the perspective of multidimensional ecological development. And the construction of ecological writing can be divided into three modules: genre and rhetorical knowledge (textual embodiment of rhetorical function), cognitive knowledge (process and strategy direction) and sociocultural knowledge (interaction of discourse community). However, the description of English Writing ability in academic context needs to be further refined and clarified in research and teaching practice.

\section{B. Trends of Ecological Dynamic Assessment of English Writing}

The developmental and multidimensional conception of writing has posed a huge challenge to the result-oriented and summative writing assessment. The writing assessment gradually turns to the interactive mode of process, and the teaching activities and assessment activities in writing classroom are correspondingly integrated with each other. Teachers interact and intervene by evaluating learners' writing levels, and constantly adjust their teaching tasks. As Gibbs (2006) once said: the writing assessment model not only constructs the whole learning framework but also guides the learning process in all aspects.

In fact, research and teaching practice in the U.S and U.K has gone through two summative stages: the objective tests (1950-1970) and the overall assessment (1970-1986). Since 1986, it has been advocated to pay attention to the formative assessment of the writing process based on students' essay exercises and writing portfolio, and has gradually stepped into the 4th stage of Yancey's (1999) prediction, that is, making the ecological dynamic assessment of the students' writing ability development in multiple ways. Through case studies, electronic writing portfolios, interviews, text analysis, observation and other statistical data analysis, the progress of students' individual writing ability and the role of Educational institutions in the development of EAP Writing ability is overall testified from a multidimensional perspective. A preliminary study on the ecological dynamic assessment system of EAP writing ability development has emerged since then (Syverson, 1999; Fleckenstein et al. 2008).

1. Research on dynamic assessment of writing and its application

Dynamic assessment is the general term of a series of assessment methods. It can also be called as the theoretical basis of dynamic assessment of learning potential, which is based on Vygotsky's sociocultural theory, aims at exploring and discovering the students' "Proximal Development Zone" through the interaction between assessors and students (Vygotsky, 1978). The assessors provide "scaffolds" for students' learning by mainly using interventional or interactive activities. Presently, the dynamic assessment system of writing is still under construction. Previous studies have focused on the theory and practice of writing assessment based on interventional and interactive feedback and writing portfolio.

1) Scaffolding intervention

Teachers generally use summarizing assessment methods strategically, which place great emphasis on formative feedback, students' reflection and students' understanding of assessment criteria. In the process of writing, students are guided by specific steps to continue their participation. For example, Seviour (2015) describes the teaching steps of a six-week writing class: process the writing materials independently; draft writing plan; submit the final drafts of writing plans(teacher's assessment on the final plan 15\%); Write and edit the first draft of the paper (formative assessment and defense, 15\%); submit the second draft according to the feedback; teachers evaluate the final paper(70\%). In some scaffolding intervention, teachers, library staff and learning consultants jointly develop students' electronic literacy and academic writing ability in accordance with disciplinary standards (Wilkes et al. 2015).

2) Interactive feedback

In the process of students writing, teachers can identify and respond to the aspects of students' writing which are in urgent need of guidance through email feedback according to the individual characteristics of the students (Shrestha \& Coffin, 2012). Some other researchers have also observed and described the interaction patterns in the interview feedback and have analyzed the factors influencing the relationship between teachers and students' behavior in the process of feedback and the possible influence of feedback on students' cognition of academic writing (Unlu \& Wharton, 2015).

3) Writing portfolio assessment

The writing portfolio assessment is more focused on the learner's learning experience than the scaffolding feedback assessment (Romova \& Andrew, 2011). In particular, writing reflective diaries can help students understand the importance of learning experiences and enhance language cognitive, social and emotional communication skills (Kathpalia \& Heah, 2008).

Romova \& Andrew's (2011) investigation indicates that: with the help of teaching method of combining process and genre, the portfolio can provide a series of feedback materials, so that students can understand the characteristics of the 
"recursive process" of writing, and gain a deeper understanding of the genre norms of different types of discourse. And some progress has been made in academic reading and writing. More importantly, learning and assessment have been closely linked in the process of writing academic texts.

2. Research on ecological assessment of writing and its application

The ecological assessment model of writing is still in the stage of conception. The model of ecological balance believes that the writing ability development and individual experience of reading and writing are closely related. Haugen (2001) has pointed out that the language variation in early childhood can internalize the passive contact, but has obvious individual differences. The differences to a certain extent will influence their language learning ability and willingness of adulthood. And language learning is limited to the social environment. In other words, the interaction relationship between language users and the environment will affect the development of language competence. Therefore, the ecological assessment model considers environmental factors such as the groups of writing, time and place of writing, and use various methods of data collection and share the data analysis of the assessment results. Wardle \& Roozen (2012) established the assessment system of ecological writing ability at the University of Central Florida (see Table 1). The assessment system covered the composition assessment of freshmen, ethnographic assessment, writing center counseling, assessment of professional writing task, assessment of general education, assessment of horizontal and vertical writing project. Assessment and feedback were offered at different stages in different contexts for students' reading and writing ability development. The study is one of the few results which provides some reference and enlightenment for the ecological assessment of academic writing practice and research.

TABLE 1

ELEMENTS OF AN ECOLOGICAL ASSESSMENT SYSTEM FOR THE DEVELOPMENT OF WRITING ABILITY AT THE UNIVERSITY OF CENTRAL FLORIDA, USA

\begin{tabular}{|l|l|l|}
\hline Types & Key points of assessment & Assessment methods \\
\hline Writing assessment of freshmen & $\begin{array}{l}\text { Completion and process of students composition in } \\
\text { class }\end{array}$ & $\begin{array}{l}\text { Writing portfolio, before-class/ after-class } \\
\text { survey; }\end{array}$ \\
\hline Ethnographic assessment & $\begin{array}{l}\text { Learners' reading and writing skills; roles of } \\
\text { school institutions in facilitating or hindering the } \\
\text { transfer of literacy knowledge; }\end{array}$ & $\begin{array}{l}\text { Vertical case study, writing portfolio, } \\
\text { interview, classroom } \\
\text { discourse analysis; }\end{array}$ \\
\hline $\begin{array}{l}\text { Assessment of writing center } \\
\text { guidance }\end{array}$ & $\begin{array}{l}\text { Understanding how writing center promotes } \\
\text { knowledge transfer; }\end{array}$ & $\begin{array}{l}\text { Data analysis of students in Writing } \\
\text { Center; }\end{array}$ \\
\hline $\begin{array}{l}\text { Professional writing task } \\
\text { assessment }\end{array}$ & $\begin{array}{l}\text { Understanding how different programs contribute } \\
\text { to students'development assessment; }\end{array}$ & $\begin{array}{l}\text { Development \& assessment of writing } \\
\text { ability in professional fields; }\end{array}$ \\
\hline $\begin{array}{l}\text { Assessment on } \\
\text { education project }\end{array}$ & $\begin{array}{l}\text { Composition of freshmen; Electronic } \\
\text { writing portfolios during undergraduate } \\
\text { phase; }\end{array}$ \\
\hline
\end{tabular}

\section{CONSTRUCTION OF THE ASSESSMENT SySTEM}

\section{A. Writing Constructs of EAP}

As a genre, EAP writing is "the manifestation of a class of communicative events, in which members share a series of communicative purposes". These communicative purposes determine that the same genre of discourse has similar structural style and content rhetorical patterns, and related to the values and expectations of specific discourse groups"(Swales, 1990). Genre and rhetoric knowledge, cognitive knowledge, social and cultural knowledge, these three modules have provided the theoretical basis for the construction of EAP writing. Academic English writing, as communicative events, which has specific genre characteristics and rhetorical functions (genre and rhetorical knowledge), requires the Utilization of the cognitive knowledge (process and strategy knowledge) and sociocultural knowledge (academic discourse community knowledge). The author refines the composition of the three modules to facilitate assessment, as is shown in figure 1: 


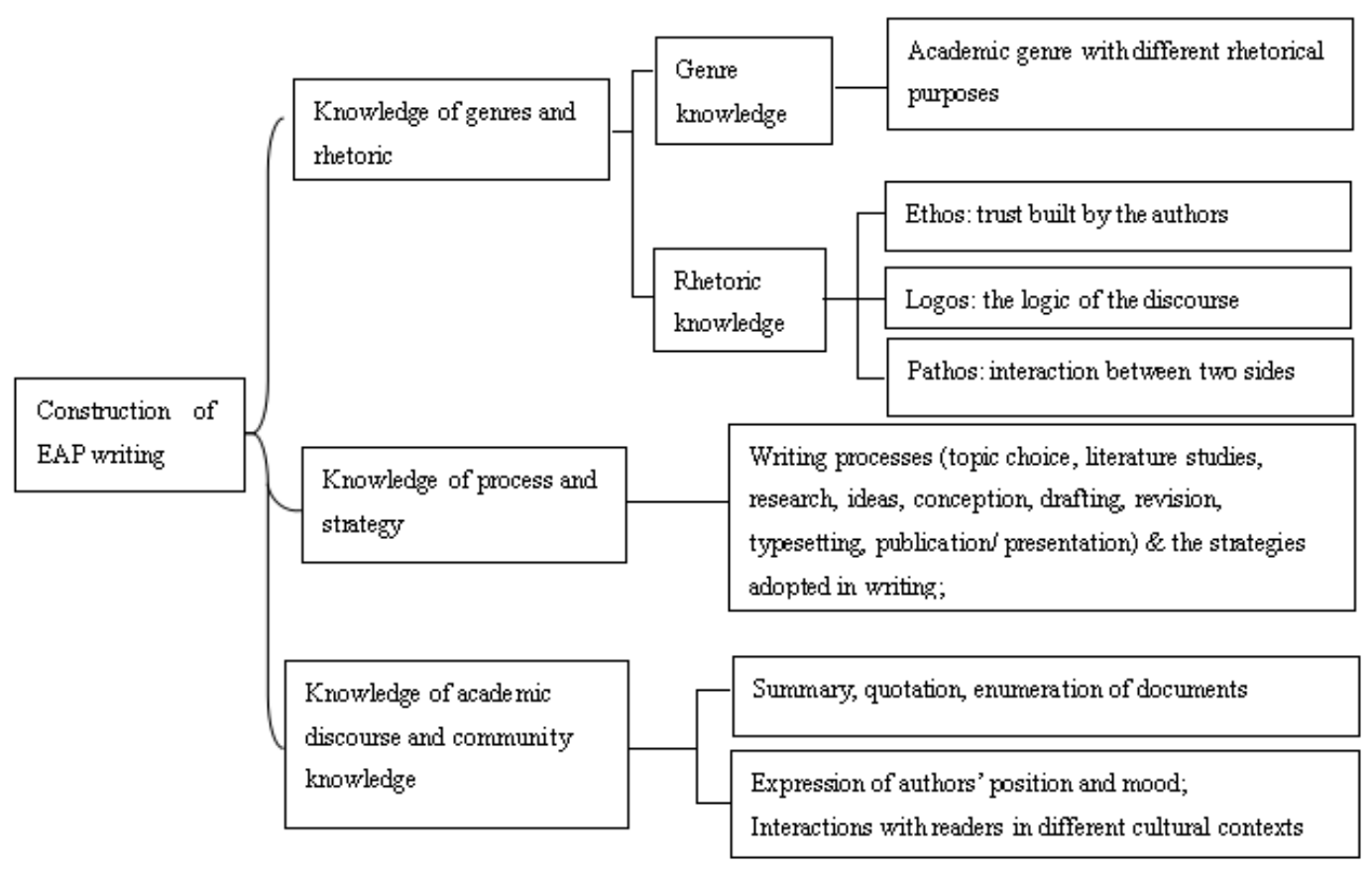

Figure 1: The Framework Construction of EAP Writing

1) Module of genre and rhetoric knowledge

Hyland (2008) points out that writing is an output activity based on the reader's reading expectation, which is derived from the reader's experience in reading the same types of text. Therefore, a good EAP writing needs to show the author's sense of context and reader's consciousness. On the basis of Aristotle's "rhetoric Triangle" in Classical rhetoric, the rhetorical knowledge required for academic writing includes an effective expression of the author's credibility, logos, and pathos. The above three elements of knowledge vary along with different EAP contexts and Different readers, which are driven by different rhetorical purposes (such as inquiry, exploration explanation, interpretation analysis, interpretation assessment, judgment showing position to propose solutions, etc.). It is characterized by different text structure, phrasing style, mood and other genres, which constitute the genre knowledge of EAP writing.

2) Module of process and strategy knowledge

Since the middle of 1980s, the social cognitive process and strategies of EAP writing continue to be the focus of practical study from the perspective of academic language competence theory (Xu 2015). The process and strategy knowledge covers multidimensional abilities, such as literature search and research, analyzing, drafting, revision, final layout, publication, presentation, problem finding, problem analysis, judgment, problem solving, etc.

3) Community knowledge of academic discourse

The reason why "community knowledge of academic discourse" is listed as a single module is mainly based on the consideration that EAP writing learners have the status of English apprenticeship. They not only need to master English cultural knowledge, moreover, it is necessary to acquire the academic and cultural knowledge. The selection of rhetoric knowledge based on academic discourse community is closely linked with the module of process and strategic knowledge, which contains the norms cited in the literature summary. That is, the text borrowing and intertextuality knowledge (Hyland, 2009). The academic writing, considered as a way to establish academic identity through socialized interactions with members of the academic community, refers to the patterns of author's position and mood expression and interaction with readers in different cultural and disciplinary contexts (Myers 1989; Hyland, 2002).

It should be pointed out that there are some repetitions in the modules designed by the author. For example, "the expression of the author's position and mood and the mode of interaction with the reader" can be placed in the module of "academic discourse Community knowledge". It can also be used as the content of the module "genre and rhetoric knowledge". Writing construction involves many variables, and the influence of different variables on the development of academic writing ability needs to be further identified and classified.

\section{B. Ecological Dynamic Assessment System for the Development of EAP Writing Ability}

In the construction of EAP writing, the focus of the development of academic writing ability changes from text to human-oriented interaction, and pays more attention to the reasons of learners' writing style, the cultural background and cognitive characteristics, and so on. Since the first half of 2015, the author and the members of the course team have offered a series of courses in EAP writing at Tianjin Polytechnic University to explore the scientific and effective assessment of EAP writing ability. Based on the theory that interaction between language and environment can promote language development (Haugen, 2001), We try to establish an ecological dynamic assessment system for the 
development of EAP writing ability in the context of direct classroom and indirect school education, as shown in figure 2 .

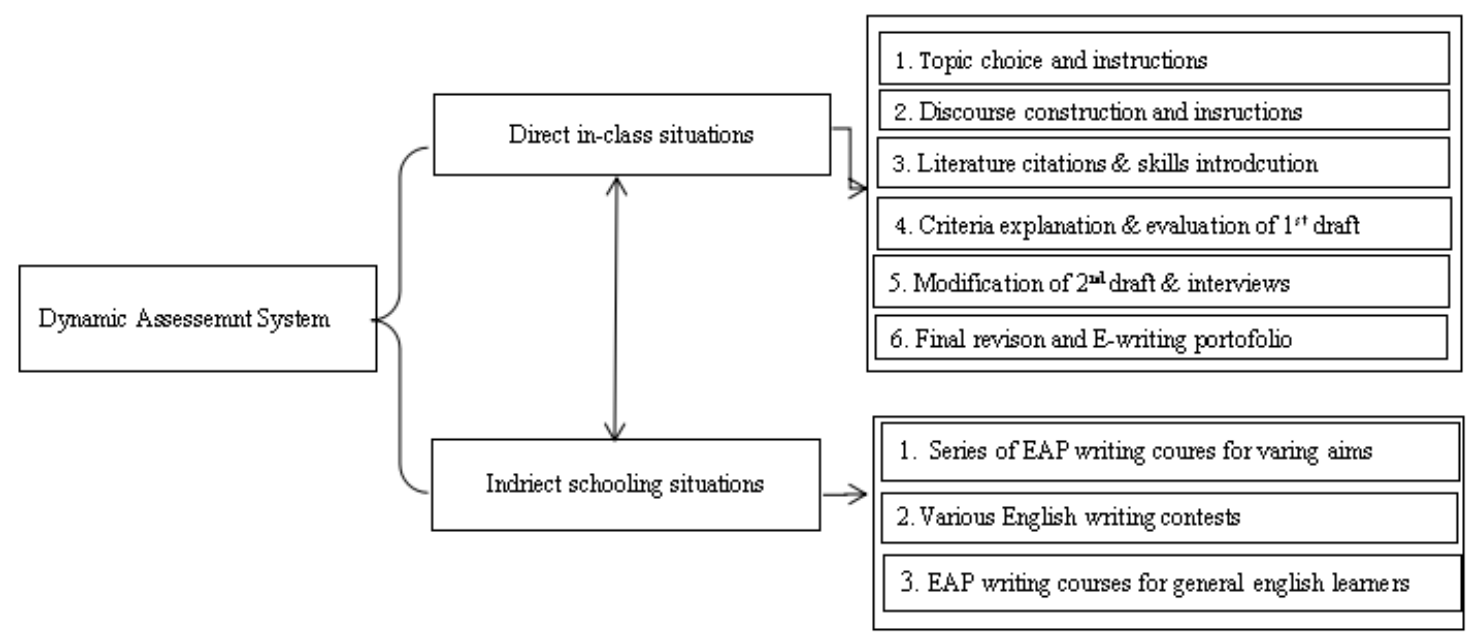

Figure 2: Ecological Dynamic Assessment System Construction of EAP Writing Ability Development

1. Assessment of direct classroom situation

Under the project-based writing classroom environment, the EAP writing course adopts the ecological dynamic assessment method in different ecological environment, and combines the different assessment approaches with the interactive teaching model. The author employs classroom teaching and ecological dynamic assessment to realize the ecological transfer of knowledge among three modules of genre and rhetoric knowledge, process and strategy, academic discourse community knowledge.

1) Topic choices and instructions (process and strategy knowledge)

Study groups, composed of three or four students with same majors, search the literature and determine the common writing themes, and identify the problems that need to be solved. Teachers' intervention mainly lies in explaining the information retrieval and document identification. Members of the group with a close academic background will review the literature on the same subjects. Students are expected to organize the academic communities in and out of the classroom to create conditions for the establishment of a text framework and the exchange of initial drafts.

2) Discourse construction and instruction

After setting up the text frame, students respectively clarify the information organization and logic levels through the mind map and the text outline. The groups comment on whether the text structure is reasonable. To enhance the level and clarity of text organization, teachers intervene to explain rhetorical strategies and genre structures, such as: paying attention to points of common information based on different rhetorical purposes and readership, how to create the credibility of the author, how to establish the information interconnection with the readers, how to satisfy or even exceed the readers' expectations, and how to convince the readers, etc.

4) Literature citations and skills introduction

Teachers are involved in explaining the norms and techniques of literature citation according to the questions raised by students, training students to use the literature creatively in class, quoting and summarizing and evaluating the literature.

5) Criterion explanation and assessment of $1^{\text {st }} \mathrm{draft}$

Teachers ask questions in terms of the description of the assessment criteria for text writing and the mutual assessment from five aspects: content, structure, expression, grammar and norms. After the completion of the first draft, members of the panel discuss the writing texts according to the criteria and make suggestions to each other for revision. (see Table 2) 
TABLE 2

DESCRIPTION OF SELF-ASSESSMENT AND MUTUAL ASSESSMENT STANDARDS FOR TEXT WRITING

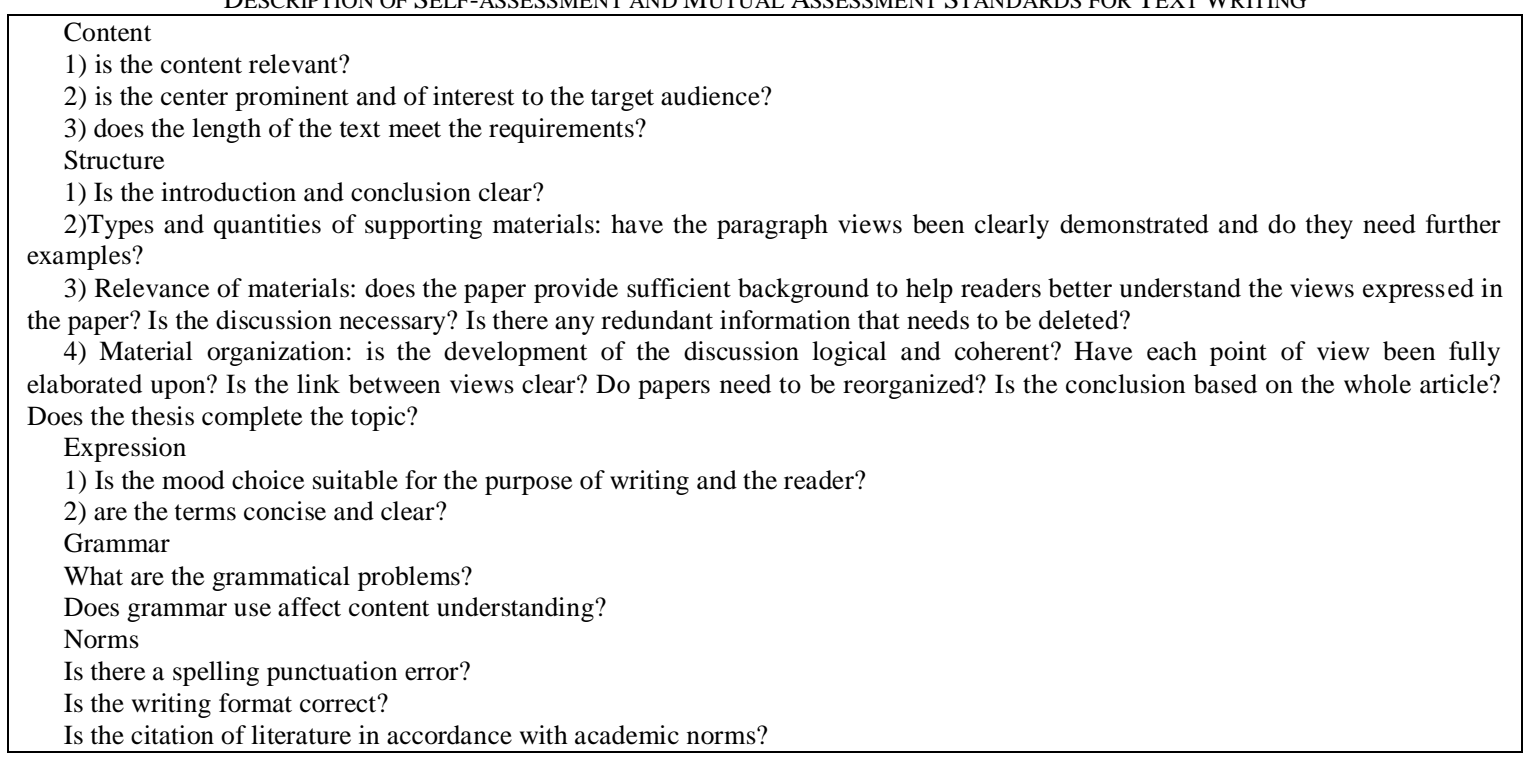

5) Modification of $2^{\text {nd }}$ draft and interviews

Students make two revisions to the first draft, On the other hand, teachers focus on assessing the problems in the logical level and academic discourse community knowledge. Teachers note problems of the first drafts in terms of text structure and interview students one by one, while the second edition focuses on lexical grammar and norms. The two interviews are aimed at learning more about students' personality and individual writing intention and writing experience, and helping students express their writing ideas clearly and completely.

6) Final version and electronic writing portfolios

After the final draft is completed, three drafts of two or three themes in a semester are compiled into their respective electronic files, and a reflective diary is added. In the diaries, students are expected to describe the difficulties and skills used in the various aspects of writing, such as setting up a framework for selecting topics for literature retrieval, drafting, revising, and finalizing, etc. The teacher finally evaluates each student at the end of the term.

2. Assessment of indirect schooling situation

In addition to the direct classroom ecological situation, the teaching of various EAP writing courses is relatively independent and interrelated. Together with the English writing contest activities, the indirect school education ecological situation is created and the campus atmosphere of English writing is created. In addition, teachers analyze the writing texts and the students' writing experience resources through students' electronic writing portfolio, which further promotes the ecology of dynamic assessment of EAP writing ability.

1) Series of courses in EAP writing

Students are trained to complete one or two types of academic writing tasks with different rhetorical purposes, for example, "EAP writing: Multiculturalism\& Speculation" is based on the reading of a single article. Analytical writing of literature reading aims to train the writing of illustrative papers and argumentative papers. The research tries to establish the interrelated students' electronic writing portfolio to evaluate the development of students' academic writing ability through longitudinal comparison.

2) English writing contests

Writing contest activities play a positive role in creating an overall English learning atmosphere to evaluate students' writing ability. One of the contest activities is the Love Onion Book Review Writing contest. The competition is held every year in the first half of the year, which is mainly for learners of Advanced English or Academic Exchange English (classroom lectures). And an online reference templates for book review writing before the competition. After the submission of the book reviews, they are evaluated manually, and the excellent book reviews are reviewed after the competition. Another competition that enables students to develop their writing skills through participation is the selection of students in the "FLTR Cup" English Reading and Writing Competition, which is organized once a year in the second half of the year. The selection of the preliminary match is in the form of automatic grading of online evaluation by pigai.org (a well-known online writing assessment system based on the massive English language corpus) and manual grading of the experts. The experts give feedback and text analysis to the winning works through email or face-to-face interview, thus guiding the winners to step into the provincial and national competitions.

3) EAP teaching in General English\& for English minors

They are designed for students of different grades, and the teaching and assessment model is the same as the series courses of EAP writing. The purpose of this system is to improve students' EAP writing ability in many ways. in order to make a comprehensive assessment of students' individual and group writing ability development, the future research 
and practice of the indirect school education situation assessment system lies in collecting the participation data of different kinds of students' EAP writing courses and writing projects (competitions), building students' electronic writing portfolios, adding interviews and scaffolding intervention.

\section{CONCLUSION}

This paper aims to create an ecological dynamic assessment of EAP writing ability by combining the educational situations of direct classroom teaching and indirect schooling together. The ecological dynamic assessment of EAP writing ability attaches great importance to the interactions among the individual language students, teachers and educational environment in the process of writing. Teachers find out problems existing in the process of students' writing and to intervene in time to provide effective assistance through classroom observation, reading students' exercises and introspection diaries. teachers carry out humanistic analysis and text analysis in different writing courses and writing projects to promote the sustainable development of students' writing ability through the establishment of writing portfolios.

However, as an emerging interdisciplinary research field in Second Language Acquisition, the ecological dynamic assessment system for the development of EAP writing ability is still at the preliminary stage and under construction in China. For example, the description and assessment of the two models of process and strategic knowledge, academic discourse community knowledge, all of the research elements mentioned above need to be further improved. In this way, students can be promoted more effectively to improve their EAP writing ability, including the ability of expressing their ideas and moods in academic discourse as well as the ability of literature research.

\section{ACKNOWLEDGEMENTS}

The research in this paper was supported by the Teaching Reform Project of Tianjin Polytechnic University: "A Study on the ESP Curriculum System of College English at TJPU under the Background of 'Double First-class' Construction-Taking Textile Engineering as an Example”. (NO. 2017-3-31)

\section{REFERENCES}

[1] Beaufort A. (2007). College Writing and Beyond: A New Framework for University Writing Instruction. Logan, UT: Utah State University Press.

[2] Fan Junjun. (2005). Review of Eco-Linguistics. Foreign language Teaching and Research, 68: 110-115.

[3] Fill A \& Mühlhusler P (eds.). (2001). The Ecolinguistics Reader: Language, Ecology and Environment. London: Continuum.

[4] Fleckenstein K S et al. (2008). The importance of harmony: An ecological metaphor for writing research. College Composition and Communication, 60: 388-419.

[5] Gibbs G. (2006). How assessment frames student learning. In Bryan C Clegg K (eds.). Innovative Assessment in Higher Education. Abingdon: Routledge.

[6] Haugen E. (2001). The ecology of language. London: Continuum.

[7] Hyland K. (2002). Genre: Language, context, and literacy. Annual Review of Applied Linguistics, 22:113-135.

[8] Huang Guowen. (2016). The rise and Development of Eco-Linguistics. Chinese Foreign languages, 48:9-12.

[9] Hyland K. (2008). Metadiscourse. Beijing: Foreign Language Teaching and Research Press.

[10] Kathpalia S S \& Heah C. (2008). Reflective writing: Insights into what lies beneath. RELC Journal, 39: 300-317.

[11] Lantolf J P \& Poehner M E. (2004). Dynamic assessment of L2 development: Bringing the past into the future. Journal of Applied Linguistics, 78: 49-72.

[12] Llosa L, Beck S W \& Zhao C G. (2011). An investigation of academic writing in secondary schools to inform the development of diagnostic classroom assessments. Assessing Writing, 16: 256-273.

[13] Myers G. (1989). The pragmatics of politeness in scientific articles. Applied Linguistics, 10: 1-35.

[14] Pecorari D \& Shaw P. (2012). Types of student intertextuality and faculty attitudes. Journal of Second Language Writing, 21: $149-164$.

[15] Qixi. (2015). The Construction of academic English Curriculum Module in the context of Transformation of College English. Foreign Language World, 87: 61-68.

[16] Romova Z \& Andrew M. (2011). Teaching and assessing academic writing via the portfolio: Benefits for learners of English as an additional language. Assessing Writing, 16: 111-122.

[17] Seviour M. (2015). Assessing academic writing on a pre-sessional EAP course: Designing assessment which supports learning. Journal of English for Academic Purposes, 18: 84-89.

[18] Shrestha P \& Coffin C. (2012). Dynamic assessment, tutor mediation and academic writing development. Assessing Writing, 17: $55-70$.

[19] Slomp D H. (2012). Challenges in assessing the development of writing ability: Theories, constructs, and methods. Assessing Writing, 17: 81-91.

[20] Smit D W. (2004). The End of Composition Studies. Carbondale, IL: Southern Illinois University Press.

[21] Swales J M. (1990). Genre Analysis: English in Academic and research Settings. Cambridge: Cambridge University Press.

[22] Syverson M A. (1999). The Wealth of reality: An Ecology of Composition. Carbondale, IL: Southern Illinois University Press. 
[23] Unlu Z \& Wharton S M. (2015). Exploring classroom feedback interactions around EAP writing: A data based model. Journal of English for Academic Purposes, 17: 24-36.

[24] Vygotsky L S. (1978). Mind in Society: The Development of Higher Psychological Processes. Cambridge, MA: Harvard University Press.

[25] Wardle E \& Roozen K. (2012). Addressing the complexity of writing development: Toward an ecological model of assessment. Assessing Writing, 17: 106-119.

[26] Wang Jinjun. (2007). Eco-Linguistics: a New Perspective of linguistic Studies. Journal of Tianjin Institute of Foreign languages, 58: 53-57.

[27] Wilkes J, Godwin J \& Gurney L J. (2015). Developing information literacy and academic writing skills through the collaborative design of an assessment task for first year engineering students. Australian Academic research Libraries, 46: 164-175.

[28] Xu Fang. (2015). Review of academic English writing. Foreign language Teaching and Research, 64: 94-105.

[29] Yancey K B. (1999). Looking back as we look forward: Historicizing writing assessment. College Composition and Communication, 50: 483-503.

Jinzhu Zhang, Male, lecturer at School of Humanities of Tianjin Polytechnic University, Tianjin, China. His research interest lies in the Applied Linguistics and Language Testing Theory \& Practice. 